\title{
The punished and the lamenting body
}

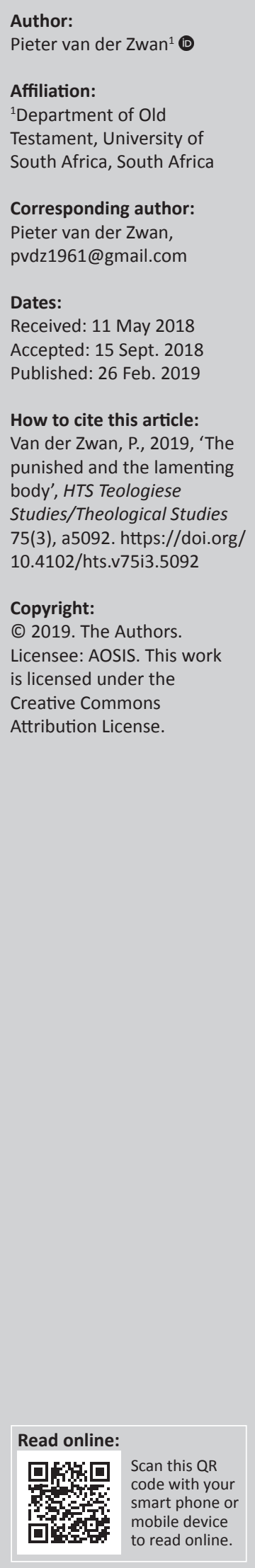

The 5 lamentations, when read as a single biblical book, outline several interacting bodies in a similar way that dotted lines present the silhouettes and aspects of a total picture. Each also represents action, building into a plot that can be interpreted psychoanalytically to render its depth and colour content. In addition, by focusing on the body and its sensations, this study can facilitate the visceral experience of the suffering of collective and individual bodies by the recipient.

\section{Introduction}

This study is dedicated to my doctoral supervisor, Prof. Eben Scheffler, whom I met for the first time in 1993 at my final oral examination for the BD degree before we started our long journey about the celebration of the body in the book of Song of Songs. During these 25 years, we have become deep friends where conflict can be accommodated, just as it is in the collection of testimonies about crisis and traumatic experiences of God, testimonies that have inspired us both, also in our ageing bodies. One particular expression of this struggle Prof. Scheffler once verbalised as being imprisoned by the body, when I accidentally made him walk in the wrong direction at an airport some years ago. This almost desperate statement has stayed with me and guided me to a biblical book where the body is not only the jailor but also the prisoner, a book riddled by guilt feelings but ultimately crying to God from this imprisonment.

The body is mostly negatively portrayed in the Hebrew Bible. The following examples suggest that these portrayals seem to be mainly in the Ketuvim apart from the unclean body in Leviticus: the body at the edge of existence in Job; even the body, lovesick, in Song of Songs; the body in (possible) poverty in Psalm 22 and the dreamt body in Daniel 2 where the body is described from the outside unlike the bodily experiences in the book of Lamentations, which represent the traumatised body par excellence from the inside.

It is probably because the body plays such a strong seemingly metaphorical role in these depictions of suffering that it has not always been taken seriously and why it is not even mentioned once in a more popular work such as that of Crüwell (2012:103-126), which is meant more as a spiritual guide than a commentary. Neither is it even once referred to in any of the first 6 chapters on Lamentations as first part of a work on lamentation in general in the Hebrew Bible (Lee \& Mandolfo 2008). That a specific 'vehicle' is repeatedly employed to ascribe certain attributes to a 'tenor',1 a distinction that Ivor Richards (1936) makes in his interactions theory of metaphors indicates an unconscious psychological reason underlying the choice of a particular metaphor, which is therefore not arbitrary according to the psychocriticism of Charles Mauron (1963). Although the latter had an individual as author in mind, one could apply his thinking to the redactor(s) of a biblical book representing the collective unconscious of the particular culture within which it is created and finalised.

The aim of this study is to reconstruct bodies from their fragments scattered through the text of Lamentations. This is done in the first part by an often statistical analysis of the mentioning of the body in the text, whereas the latter part focuses on interpretative synthesis of the found details.

\section{Overview of the body in lamentations}

The Book of Lamentations is a collection of 5 originally independent songs that are brought together like body fragments or limbs to bewail the collective body, Jerusalem. For that reason, these body parts should not be assumed to have belonged to the same person, but as being

1.Other scholars call these facets figure and ground (Tsur 2000:passim), whereas cognitive linguists use the terms, source and target, respectively (Kövecses 2002:15ff.).

Note: The collection entitled 'Eben Scheffler Festschrift', sub-edited by Jurie H. le Roux (University of Pretoria) and Christo Lombaard (University of South Africa). 
somehow 'transplanted' into and forming a new body, a dismembered body 're-membered' in mourning. That the first 2 and the last 2 chapters have exactly the same number of verses, 22, and the middle one 66 , a multiple of 22 , might suggest that the body is also perfectly symmetrical with the longer torso flanked by equal length limbs. In addition, symmetry has also been noticed in the first 2 chapters, splitting each of them in equal-length parts (Berges 2002:80). This could tie in with the acrostic nature of the first 4 chapters: they could all point towards establishing order in the body of the text, and perhaps also in the body which is in this way contained. The literal body has almost disappeared in the last chapter even when the mind is still shaped by it (vide infra).

On the other hand, these 5 chapters mention quite different numbers and different kinds of body parts and therefore also portray at least 5 different bodies. When the total of 99 times (vide infra) where the body is mentioned is taken into account, each chapter should on average mention 14 body parts, except the third where there should proportionately be 42 . Only chapter 4 complies with that. The body is therefore unequally spread over these 5 chapters.

Chapter 1, like chapter 3, roughly covers the whole body from top to toe but focuses on the head as is the case in all the chapters. In the second just as in the fourth chapter, the lower limbs are not mentioned but both mention the breast. Although the emphasis is still on the head, more attention is given to the torso (and more particularly the internal organs) and the hands than in any other chapter, specifying even the right hand twice. It also mentions body parts proportionately more than the other chapters. Chapter 3 mentions the inner body parts more than any other chapter. Chapter 5 , the one without acrostic arrangement even if it is still suggested by its 22 verses as it is in Psalms 33, 38 and 103, mentions the least body parts.

In total $99^{2}$ times, one of the 29 body parts is mentioned, spread over the 154 verses of the book. Furthermore, it means that, on average, a body part is mentioned in roughly every 2 of 3 verses. This competes well with the best book for the body, Song of Songs' 8 chapters with 30 body parts (with another 6 suggested) in $65^{3}$ times spread over its 117 verses, and with the book of Job (but then in 42 chapters, being 1070 verses) with one of its approximately 68 body parts occurring

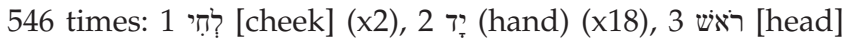

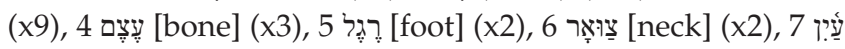

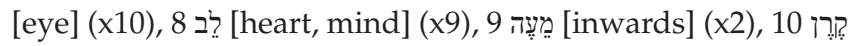

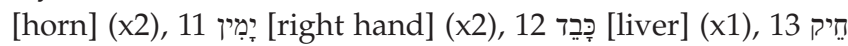

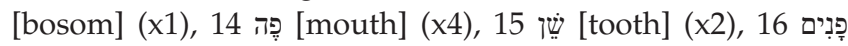

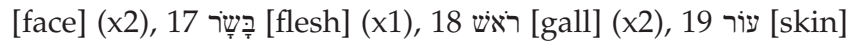

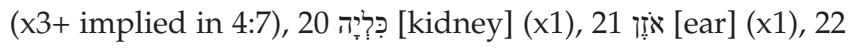

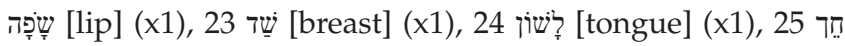

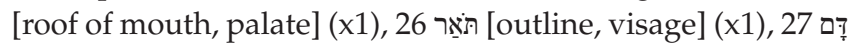

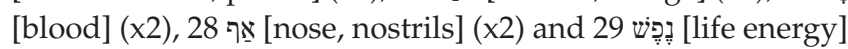
(x11). This distribution reflects more or less the same

2.That is, when שु is included as a part of the body; when not, then 87 times.

3.That is, when שִ is included as a part of the body; when not, then 58 times. proportions found in the Hebrew Bible in total, except that פָּנִים [face] should have occurred more, which is the body part that is elsewhere found the most (Baumann 2003:246). It means that the face is somehow hidden, probably because of shame (vide infra). This assumption is strengthened by the

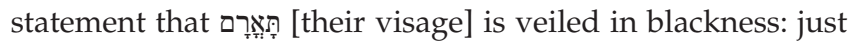

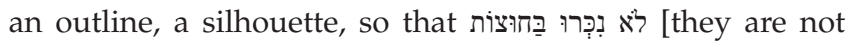
recognised in the street]. This last-mentioned reason could explain why no שער [hair] is ever mentioned, even when one could have expected it as part of behaviour expressing mourning, or it is not mentioned precisely because it has been shaven as a sign of mourning. Yet, that almost half, 13, concern the face probably means that the facial area is not (as it is probably covered) used to express but to experience the trauma.

More than a third, 10, in this list concern internal and therefore mostly invisible organs or body parts (vide infra): liver, heart, inwards, bones, flesh, gall, blood, reins, palate and life force and deal with inner experience instead of an external image. The only body parts that occur in all 5

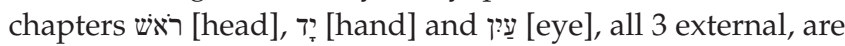
the ones that are used literally more times (but not always) than the others. The eye, in the second position, is so powerful that it affects the life energy, according to 3:51. One would have expected life energy to be amongst this common denominator for all chapters, but it is not.

In addition to the ראש [head] and the עִ ראיו [eye], 8 other facial features occur in the literal sense: לִ פִֶ [cheek] (1:2; 3:30), [mouth] in 2:16; 3:29, 38, של [teeth] in 2:16 and 3:16 perhaps,

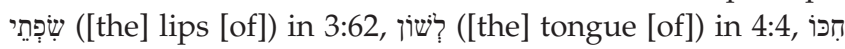

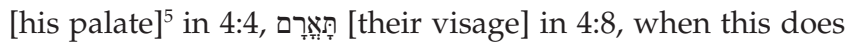
not mean 'outline' and אַפַּינו [our nostrils] in 4:20. This is apart

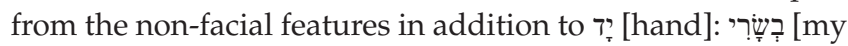
flesh] in 3:4, וְעוֹרִ [and my skin] in 3:4; 4:8; 5:10 (implied in 4:7,

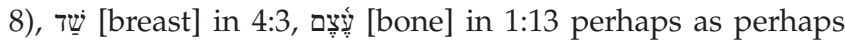
also in 3:4 (like teeth in 3:16) and 4:8 and 꼬 [blood] in 4:13, 14 .

Some of these 16 body parts are, however, used elsewhere, metaphorically, such as ראש [head] in 2:19. That means that the remaining body parts mentioned in Lamentations, that is, more than 12 , and so almost half, are only used metaphorically. ${ }^{6}$ While only one out of 14 body parts, כִּר [at the head] in 4:1, in the second last chapter is used metaphorically, only 2 out of 10, עראשינו [our head] in 5:16 and [our eyes] in 5:17, are used literally in the last chapter. In fact, in the first 3 chapters, the body is also used mostly metaphorically, making chapter 4 to stand out as different.

Although פָָָּרָם [face] [their visage] refer to the same body part, 2 different words have been used in Hebrew, making them to be somewhat different and therefore counted as 2 parts.

4.Only the generic word is given when various derivatives appear in the text.

5.The only one that could be non-visible.

6. שִ [life energy] is ignored in this calculation, as it is difficult to decide what its exact meaning in each case is. 


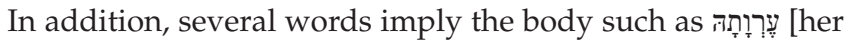

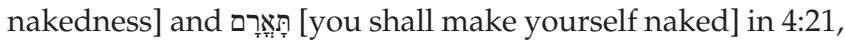

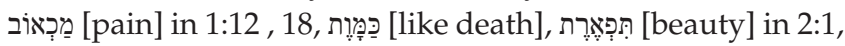

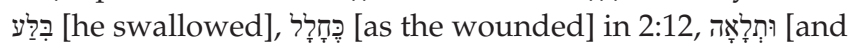

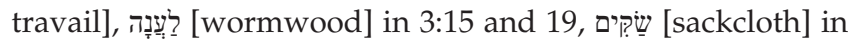

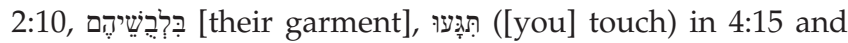
[you shall be drunken]. Many verses do not mention any body parts but in 2:19 (6), ${ }^{7} 3: 4$ (3) and 4:8 (3) they are clustered. In 2:19, ראש [head] is used metaphorically twice, once for locality and once for temporality.

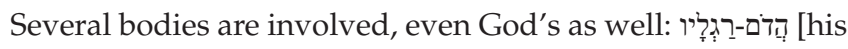
footstool] $]^{8}$ in 2:1 (foreshadowing God's trampling in 3:34) implying God's feet, and especially God's hand in 1:14, 2:3, $2: 4,2: 8,3: 3$ and $4: 2$ where the potter could perhaps refer to God, but in the context seems unlikely as it suggests a product of lower value. Only the singular is used for God's hand and one can assume that it must refer to God's right hand though this qualification (i.e. being the right one) would have been redundant if God had no other hand. ${ }^{9}$

In 2:3 God's body, or at least its anger, is like a burning fire, which has an implied metaphorical mouth in 4:11 as well

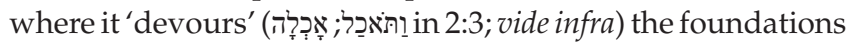
of Zion, just as God בִּ [swallowed up] Jacob's home. One wonders whether God's devouring is a projection, even if it is portrayed as if it happens in anger. In 3:38, God's mouth is explicitly mentioned, but then for speaking. This is incidentally the chapter where the mouth features the most, and then for each of the 3 'parties' in the suffering: the sadistic mouth and lips of the perpetrators in verses 46 and 62, respectively, that of the screaming victim and then of God speaking. Just as is often, the case in the Hebrew Bible nose] expresses his anger in 4:11, metonymically condensed into the same noun. Unmentioned but implied are God's eyes in 3:50, but God's ear ${ }^{10}$ (ָำ your ear; just one!) $)^{11}$ in 3:56 and פface $]^{12}$ in 2:19 are explicit in the text. All these 7 body parts of God are external just as a physical image would have done $^{13}$ although they often reflect God's inside, God's emotions. This means that the assertion that body parts mentioned in the Hebrew Bible does not reflect the visual but only the functional characteristic, as Wolff (2002:23) claims with his notion of their synthetic nature, is not completely true. Outside of Lamentations inner organs are, however,

7.The length of this verse due to an extra stich is not because of the inclusion of a gloss, as all variant readings contain it (Frevel 2017:189).

8. Here, it is Zion as an extension of the ark of the covenant in 1 Chronicles 28:2 or the temple in Psalm 132:7 but still less than the earth in Isaiah 66:1.

9.Wagner (2010:138) claims that the left side or hand of God is mentioned twice in the Hebrew Bible but does not give the textual proofs thereof. It is, however, not listed by Baumann (2003:246) amongst the body-parts that have been attributed to God (cf. also Markschies 2016:48; Schart 1999:30). Yet, Psalm 19:2 uses the dual form,

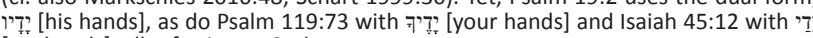
[my hands], all referring to God.

10.According to Wagner (2010:128), the ear was a relatively late development in Israel's religious consciousness, the more so that textual became more important than visual portrayals of bodies, where ears were often absent.

11.See footnote 12 .

12.This could also just be prepositionally meant as 'before'.

13.They are all amongst the 10 most often mentioned body parts of God in the Hebrew Bible (Wagner 2010:137) sometimes attributed to God, such as לב [heart], which is not only listed by Wagner (2010) or Brown, Driver and Briggs (1907), but also by Baumann (2003:246), or as מֵעי [insides, heart] as in Jeremiah 31:19. In Lamentations, apart from God's hand and feet, the focus is firmly on God's face, where the anxious victim looks for mercy.

Virtually, all of these suggest God's violence. One is tempted to interpret these references as metaphorical in the sense of anthropomorphic but there is no need to do so, if one takes the views of Sommer (2009:passim) into account that deities were actually regarded as embodied at the time.

In 2:19, a watch period and the street (as in 4:1, i.e. at the intersections according to Dhorme 1963:30) also seem to be a body, metaphorically. Inversely, the bodies of children become a metaphor, פִּרִים [their fruit], in 2:20.

Except for chapter 3, the 'protagonist' body is either the collective body of Jerusalem, and more specifically the temple sanctuary, as heart of the whole of Judah, or Edom (vide infra) tying in with the thinking of Mary Douglas (1966:passim) that the individual body is symbolised in the social or collective body. Radical transformations of the body can make them into 2 virtually different bodies. This is the case with the former leaders or elite who used to have the ideal skin colour of white and red in 4:7 just as the male beloved in the Song of Songs 5:10 who in Song 5:14 also has the סַפִּיר [sapphire] mentioned in Lamentations 4:7. Frevel $(2017: 286,287)$ seems to see this skin as almost transparent as the rosy colour is because of the underlying veins. This excessive idealisation is a typical reaction to trauma where reality is split into 2 simple opposites like צַח [they are whiter] in 4:7 and [it is blacker] in the very next verse.

Those men are now in 4:8 blacker than coal perhaps because of being burnt as is the case in Job 30:30. There is also reference

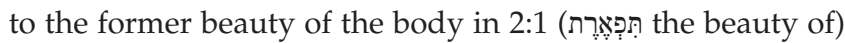

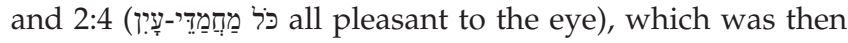
like a celestial body: in heaven whence it was thrown down to earth. This reminds of the female beloved whose beauty is likened to the dawn or morning star, the moon and the sun, suggesting the heavenly hosts in the Song of Songs 6:10.

Likewise are the golden (perhaps celestial) bodies of the sons of Zion in 4:1-2 thrown down in the street and regarded as potter's clay. It is not their intrinsic value as the traditional translations have it, but their attributed value when the emendations of Hillers (1992:137-138) are accepted: the $\square$ in

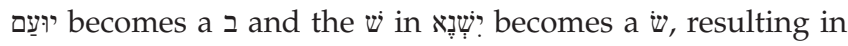
'How gold is despised! Good gold is hated'. This also reminds of the glorified male body whose head is of gold in Song of Songs 5:11a and who is rooted in a golden socket in 5:15b, perhaps a merism to suggest that his whole body is gold. One can associate this image in Lamentations 4 even further to the dream statue whose head is of gold in Daniel 2:32 but whose feet are partially of potter's clay according to the next verse (cf. also Van der Zwan 2018). 
Perhaps, this is the same body as the battered body in chapter 3 , which is also that of a male body. At first, it seems that he has been a witness rather than a victim, as he רָָ [has seen] rather than felt the violence. This might be because the traumatised body 'switches off' during the emergency as a way to focus on defence and thus to survive. The first verse suggests corporal punishment and in the second, he seems to be blind, perhaps confirmed by 3:6a and taken up by 4:14, 17 again. The word, ידז [his hand], in verse 3 is almost a euphemism for violence, and therefore, by focusing on it, renders the rest of the body of the perpetrator, in this case

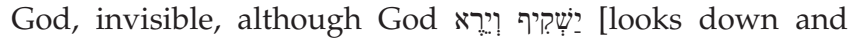
beholds] according to 3:50 (vide supra), yet seems to be deaf according to 3:56 [vide supra], exactly as it happens in such circumstances (Scarry 1988:24). In verses 4, 6a, 7, 9a and even 10 , there is the intimation of an imprisoned - confirmed in verses $34,53,55$ and 4:20 - and even tortured body, which, as being arrested, has come to a halt, perhaps also because of its broken bones in 3:4. The density of verse 4 with respect to bodily concentration and obsession suggests the suffering of the total body as is also the case in Job 10:11: flesh, skin and bone are not limited to any specific body part (cf. also Frevel 2017:208). When the flesh recedes, the skin can show the contours of the skeleton, which augurs death (Frevel 2017:207; Schroer \& Staubli 1998:234-235). ${ }^{14}$ The conditions in this prison made it feel like the grave, if $3: 4 \mathrm{~b}$ is thus understood.

That he can speak about it in the first person after his possibly voiceless cry (cf. his sighing in verse 56) in 3:8 and his broken teeth in 3:16 might mean that he could have recovered somewhat, although the wounds (cf. 2:12) and later perhaps the scars are signs by which the formerly dismembered body are remembered. That is perhaps why body language speaks so loud in these Songs: 2:10, 15, ${ }^{15} 16,19$ and 3:29 where he progresses from body language to verbal language in 3:55 and 56. This also ties in with the bodily role the victim is forced into, over against the perpetrator who is experienced as bodiless speech (Scarry 1985:33). To speak is a relief from the lonely and invisible suffering inside the body.

Now that he can somewhat walk again, his instability, imbalance and lack of coordination make him derail from a straight and 'strong' path according to verses 9c and 11a. He has regressed to the fragmented body of the psychologically still immature infant before the mirror image stage (Lacan 1949:449ff.) if verse $11 \mathrm{~b}$ is taken into account.

According to Leder (1990:91), the healthy ('rich') body becomes almost 'invisible' to its owner, compared to the 'poor' and painful body that completely fills the mind. On the other hand, when these negative experiences become too extreme, that is, with posttraumatic stress disorder sets in, this turns into dissociation, because the traumatic sensations and feelings are not synthesised into a symbolic form and then incorporated into a personal narrative. Excessive arousal interferes with memory and leaves fragments rather than

14.See Job 33:21-22.

15. Here, it is apotropaic according to Schroer and Staubli (1998:173). linear speech (Van der Kolk \& Fisler 1995:522; vide infra). Traumatic memory becomes like a Fremdkörper [foreign body], which intrudes as flash backs just as it hides from consciousness (Breuer \& Freud 1955:32).

Neither is there a containing other according to verse 11c to emotionally hold his broken body and mind together in this trauma, as his mother would have done during that infanthood. Imprisonment and torture escalate towards his imminent execution in verse 12 as in 5:12. This only serves to extend and intensify his suffering as his kidneys instead of his heart or head have been penetrated in 3:13. The pain from the poisoned arrow (threatened in 2:4)

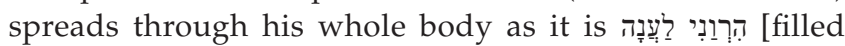
with bitterness]. This has been adumbrated by the ראש [gall] in 3:5, which is still pestering him like a posttraumatic flashback in 3:19. He probably confuses his broken teeth with gravel stones in 3:16 because he has forgotten what a healthy body is like, according to 3:17. There his life is far from well-being, and one can assume within the broader context of the book, feeling far from God. The only memories he has are those of the trauma, an idea occurring 3 times in verses 19-21.

Then comes the turning point and the healing can start. In this positive section from verses 22-41, only a few references are made to the body, and mostly negatively, with the exception of verses 38 and 41, where the hand is exhorted to metaphorically lift up the (until now too heavy) heart. This shows that the body only comes to the fore when it suffers. It is hardly capable of expressing positive emotions here, even when they occur.

While chapters 2 and 3 are about the body losing substance in being poured out, and in chapter 4 , hunger (although already foreshadowed in 1:11) and thirst in the dungeon dominate the body, chapter 5 deals in verses 4, 5, 6, 9 and 13 with the

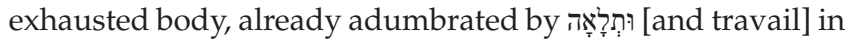
$3: 5 \mathrm{~b}$ : in verse 6 , the hand is a metonym for labour (or begging) but in 8 for exploitation. Bodies are driven to their extreme: beyond labour is rape in verse 11 and death in verse 12 . All body parts mentioned are with negative connotations in the context.

In lamentations about destruction and death, one would also expect to come across at least hints about corpses (vide infra) but the supposedly deceased one, Jerusalem or Judah, speaks out from time to time $(1: 9 c, 11 c-16,18-22 ; 2: 20-22)$. This expectation is met in 3:6 where it even involves an image of an already decomposed body, having been dead for a long time. In 3:16, wallowing בָּ [in ashes] further reinforces this mindset.

\section{Interpreting the body in lamentations}

The body is not only in physical pain and suffering but also expresses emotional distress. That is why psychosomatic experiences are described in several verses and then in the first 
person. In 3:4, the body has been under attack and perhaps even tortured over some period of time. As רنאש in 3:5, 19 where it means 'gall' is a homonym, the poison might be associated with the 'head', the meaning of the different stem, which some translation such as the LXX accepted. Koenen (2015:189) refers

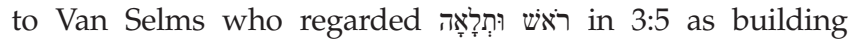
material, as ראש is also used in Psalm 118:22, although this meaning can, however, not be applied to 3:19. This reminds of both Freud (1998:154, 2008a:89, 2008b:351) and Jung (1984:116) who recognised that buildings, especially houses, often function as symbols for the body or its parts, especially in dreams. Others, such as Wutz (1930:186), read it as ראש [poverty]. If it means ' gall', internalisation of external relational objects would undermine the inside of the body and mind of the suffering one, confirmed by 3:15, for instance, where the empty stomach (so to speak) is filled with bitterness, concretised by wormwood, instead. Whether the bones in 3:4 and the teeth in 3:16 are literally broken is open for debate. The heart is faint in both 1:22 and 5:17, as if to frame the book, but hard at the heart of the book in 3:65.

Fire and water function as destructive forces as they do in Song of Songs 8:6-7. In chapter 2 (e.g. verses 3 and 4), just as in 1:13, 20, burning plays an important figurative role again as it does in 4:11, but also pouring out, ${ }^{16}$ as if a solid has been melted by fire: the liver (in 2:11 with the verb

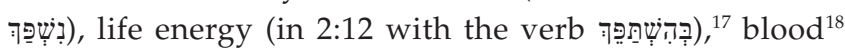

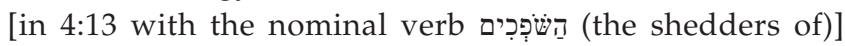
and the heart (in 2:19 with the verb are all poured out as if they are liquids, just as the eye ${ }^{19}$ in 3:49. Eventually, the victim is completely flooded in 3:54. In the case of the liver, life energy and the eye, the passive verb is used, even when, in the case of blood, the victim is the object of an active verb. That means in 4 of the 5 cases, the body is out of the subject's control. Therefore, only the heart, which is used metaphorically here, can be actively surrendered as well (vide infra). The call to do so implies control and is therefore positively connoted, as it ironically saves the body as a person (Bester 2007:168).

In $4: 1$, the golden stones (vide infra) seem to be melted as

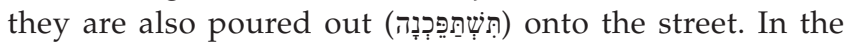
case of anger (perhaps, a kind of liquid fire) in 4:11, the emotion has already metonymically replaced the organ of (burning) anger, God's nose as in Exodus 15:7-8, from

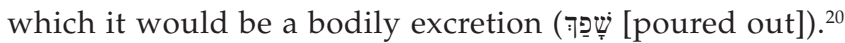
Perhaps, that is also why the human nostrils, or at least its breath, seem(s) to have some divine link or connotation

16.Bester (2007:174) points out that the verb, ע, as it occurs in $1: 8$ and $4: 21$ can also mean 'pour out', apart from 'bare, expose' and so would extend the idea of pouring out even to this verb, as an additional meaning, which would, at least unconsciously, be associated with it.

17.See also 1 Samuel 1:15; Job 30:16; Psalm 42:5; with a different verb (עור, denude, expose) in Psalm 141:8 and Isaiah 53:12. According to Kipfer and Schroer (2015:2), pouring out the נֶֶ, refers to dying.

18. In almost half of the cases where a body part or the body in total is 'poured out' using the verb, שפך, it concerns blood in the Hebrew Bible (Bester 2007:166).

19.Only one, just as in 3:51! The same verb, נִגְּר [is poured out], is used in 2 Samuel 14:14 (vide infra) and therefore probably refers to literal substance.

20.See Schellenberg (2016:109n46), referring to Job 4:9 and 32:2, 3, 5. in 4:20, as that which has been exhaled or exuded by God, ${ }^{21}$ רֵוּח [breath], is received by the human nose as anointed of Yahweh]. Dhorme (1963:81) believes that it is the acceleration of breathing during anger that connects it with the nose as Job 4:9 suggests. Slow, calm breathing in

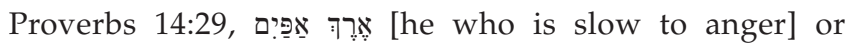

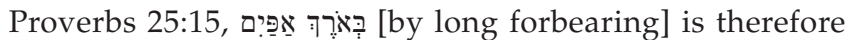

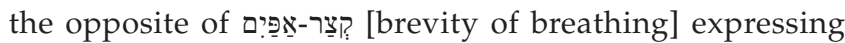
anger in Proverbs 14:17. A 'long' nose can therefore contain its anger.

One implication of such an outpouring is that the body is a container, a vessel as Kipfer and Schroer (2015) have called it. Three of these 6 instances where something is poured occur in the second chapter about the female body who represents a collective body. This reminds one that the majority of anthropomorphic, iconographic findings that have archaeologically been excavated are in the shape of a woman (2015:1), many of them vessels, not only to drink from but also for pouring out liquid. These containers point to the body's similar form and function but their contexts add more dimensions of meaning to what seems to be only an imitation of the human body.

Another implication of this outpouring is 'drying up', something perhaps hinted at by אֵֵָלוֹ in 1:4, which is usually translated as 'mourning' rather than 'drying out', an alternative meaning of a different stem, which would have suited the context better than personalising, as the roads spoken of are no longer used (cf. Schellenberg 2016:109n.48). The same word is also used in 2:8 about a wall, and therefore in the same Song as where half of these outpouring instances occur. ${ }^{22}$ Exploiting thirst is also implied in 5:4. If Kipfer and Schroer's (2015:7) claim that a dry vessel (which would happen when all has been poured out) is more fragile is accepted, then this adds to the idea of the body's proximity to death in Lamentations. The idea of drying out would, however, not apply to God who is the subject in 2:4 and $4: 11 .^{23}$

The theme of pouring out in chapters 2 and 3 and the first 2 verses of chapter 4 turns in the rest of chapter 4 to that of drying out, as is found in verses 4 and 8 , in the latter of which it becomes explicit in the verb, יבָָּ [is withered].

This is the only time in the Hebrew Bible where the liver is mentioned for a human being, the other 13 times all referring to animals (Wolff 2010:110). ${ }^{24}$ That it is mentioned at all could be because the Lamentations could have been composed under Babylonian influence where it was considered beside

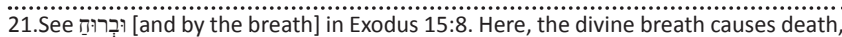

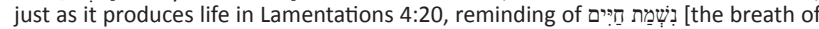
life] in Genesis 2:7.

22.Only in 5:15 would 'mourning' be the only possible translation.

23.See also Job 12:21; Psalm 107:40; Jeremiah 10:25; Isaiah 42:25; Ezekiel 7:8; 20:13, for example.

24.Wolff (2010:110) considers the possibility that in Psalms 16:9, 30:13, 57:9 and $108: 2$, different vowels could be used to change the meaning from 'glory' to 'liver'. 
the heart ${ }^{25}$ to be the most important organ because of the practice of hepatoscopy in Mesopotamia (Schroer \& Staubli 1998:76). It is associated with ראש [gall] in 3:5, 19, ${ }^{26}$ and

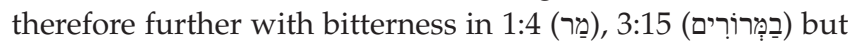
also with heaviness, which relates to the meaning of the verb, כבד Perhaps, the liver bladder (cf. Job 16:13; 20:25; Pr 7:23) has been penetrated by an arrow as the kidneys have been in 3:13 similarly to Job 16:13 (where the gall bladder is juxtaposed to kidneys as well) and 20:25.

According to Dhorme (1963:109), awareness of the inner organs represented the first psychological interests of the Semites. Emotions in Lamentations, especially sadness and anger, flow like secretions from specific body parts, which are then said to be 'poured out'. This is what Lakoff and Kövecses (1983) found in cognitive linguistics to be one of the most typical metaphors about emotions universally. Yet, Wagner (2006:98) claims that this is only seldom the situation, such as

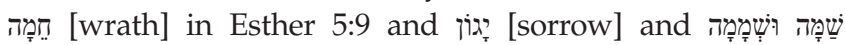
[astonishment and appalment] in Ezekiel 23:33.27,28 With humans, the product of a potter according to Isaiah 29:16; 43:1; 44:2,24; 45:9-12; 49:5; 64:7b; Jeremiah 18:11,16 and right in Lamentations, $4: 2$, for example, ${ }^{29}$ this makes even more sense.

In the case of the eye not only an emotion in the sense of sorrow, but also its concomitant substance, tears, ${ }^{30}$ are meant, as 1:16 and 3:48 make explicit. Incidentally, Dhorme (1963:78) believes that the other meaning of the word, עין [fountain], is to be explained in this way, as Jeremiah 8:23 has it. According to 2 Samuel 14:14, people become like spilt water absorbed

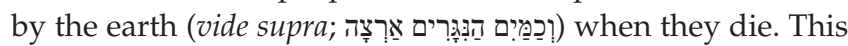
might refer to the fluids which flow from the body after dying. Both the inside and the outside of the body are on fire: the bones in 1:13, the inwards in 1:20 $0^{31}$ and in 2:11 (where burning juxtaposes being poured out) and perhaps the stomach separate from the inwards in 5:10 where it also makes the skin to be hot, a condition that reminds of the raised temperature of decomposing matter. It is, however, exceptional that the inwards are burning, although they do something similar in Job 30:27. Normally, they 'move' or 'resound' (המה) with loving desire in Song of Songs 5:4 or

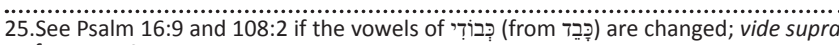
footnote 4.

26.In Psalm 16:9, the liver praises God and so also has positive connotations elsewhere. In fact, that it is so closely related to the word, כूכ [glory], could mean that there might be a relation between the two concepts, and in this way elevate the connotation attached to the liver. This could also simply happen through at least unconscious association even if there is no etymological link between the two words.

27.Note the word, ספ [cup], in Jeremiah 51:7 and Ezekiel 23:33. In addition:

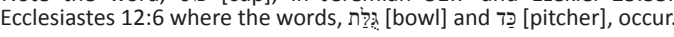

28.Psalm 2:9; 31:13 use the word, כִכְְִ [like a vessel], but the meaning could be wide than just a vessel. See in this regard also Jeremiah 19:11 [preceded in the previous

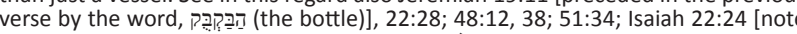

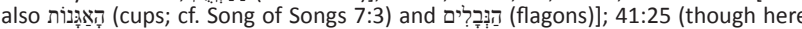
the body is not directly implied); Hosea 8:8 and 1 Samuel 21:6, although in the latter case probably referring to the penis. Isaiah 30:14 uses the words, נכלל יוֹצרים [potter's vessel] and מוברא [out of the cistern]. In some of these instances, collective body is referred to. The emphasis is always on creatureliness and fragility.

29.See also Jeremiah 18:2-7.

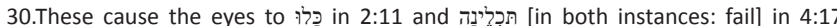
(Bester 2007:170).

31.Bester (2007:170) associates this with the burning houses of the destroyed city, and thus understands the body as metaphor for the city or the corporate body. with compassion in Isaiah 16:11 (here even musically) or in Jeremiah 31:19. The difference in emotions experienced is probably that in both Lamentations and Job, the suffering is individual, whereas in the Song, Isaiah and Jeremiah, the experience is that of 'resonating' in some way with another person. For Cottrill (2008:103), the essence of an individual lament in the Hebrew Bible is bodily suffering.

That these experiences are expressed in a culturally conditioned way is suggested by Psalm 22:15 and 2 Samuel 14:14 where the suffering person's whole being is like water

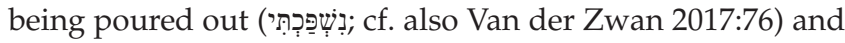
by Psalm 62:9 where a call is made to pour out their heart

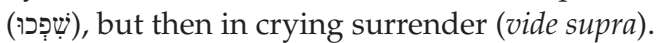

The same body part can have different connotations in the different chapters: צַּוֹארִ [my neck] in 1:14 bears the individual

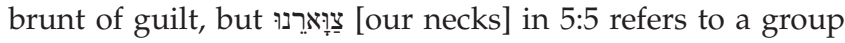
bearing a physical burden, dehumanised to become like a draught animal (Kaiser 1992:193), ${ }^{32}$ though also because of guilt. In 1:2, לחיחיָה [her cheeks] are the first body part to be mentioned and serve as the receptacle for either sorrow ${ }^{33}$ or as לֶָי [his cheek] for someone else's aggression in 3:30. In 1:13, the רגלים [feet] are the victim, but in 3:34, the perpetrator.

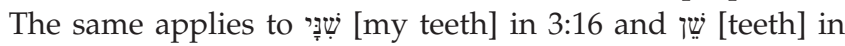
2:16, as well as קָרו [the horn] in 2:3 and 2:17, respectively. This can even happen in direct juxtaposition: in 2:3, [מינוֹ: [his right hand] would have been protective (Kaiser 1992:140), but in the next verse, it is aggressive. Just as יִיִ [the hands] in 4:10 is a metonym for the perpetrator, so $\mathbf{q}$ in $4: 13,14$ is one for the victim. This pattern of vacillating between opposites seems to be characteristic of Lamentations.

It is not arbitrary that the body is used as a possible metaphor in this context. Boase (2014) has recognised the high level of using the body as an apparent metaphor alongside physical suffering as somatisation. What is usually regarded as the metaphorical use of body parts is perhaps rather the emotional connection with the body and in this way not metaphorical. By interpreting such body references as metaphors may also be defending against the intensity of such language, as it actually prevents a voyeuristic and indifferent response by the recipient (Gillmayr-Bucher 2004:310-312, 314, 325). The correlative link between dissociation because of trauma (vide supra) and comorbid somatisation has been established as frequent and serious (Saxe et al. 1994:1329).

Three of the 5 so-called megilloth [scrolls] in the Hebrew Bible are 'feminine', and 2 are sceptical, if all 5 are not protest literature. It could well be that this is because the female body is the one that had suffered the most. As such they could be considered as somehow philosophical works critiquing a male collective body. The destroyed city of Jerusalem in the first chapter is personified as a woman (Hunter 1996:139), perhaps the raped female body (1:10) 32.See Deuteronomy 28:48, Isaiah 10:27, 14:25, 47:6, Jeremiah 27:2, 8, 11, 12, 28:10-11. 33.That is, the tears from the eyes, the body part last mentioned (in 5:17). 
mourned, and spoken of in the third person until verse 10 and so objectified. The final lamentation, on the other hand, is about the land, perhaps also as a (female) body. Yet, the only body part referring to a woman explicitly is חיק [bosom] in 2:12. She, having lost both her children and her husband, is worse off than Job who still retains his wife.

Both, however, suffer in their bodies: the second and fourth lamentations are about starvation, ${ }^{34}$ an intense bodily experience, followed by extreme cruelty, the extent of which reaches even as far as cannibalism, reminding of 2 King 6:2829: mothers eating their own children in 2:20 and 4:10, not only to satisfy their hunger but also perhaps to mercifully save their offspring from further suffering, unbearable to witness it any longer, all so typical in war (cf. Wilson 2012:105). Their children return לִבְרוֹ [as food] to the bodies

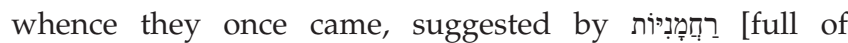
compassion], playing on the word, רחֶם [womb]: a vicious circle where aggression and violence suffered is internalised not only emotionally but also acted out in psychotic literalisation.

On another level, melancholia as avoidance of mourning gives way to a regression to the earliest pre-genital phase, the oral sadistic, which is expressed in the cannibalistic impulse, according to Karl Abraham (Jones 1927:278, 448). In this way, the mother tries to hold onto her dead child, with whom she identifies, by incorporating her love object. While the infant wants to drink in the body of the mother in 4:4, a craving still lingering on in the word, מָחָדָב [than milk], in 4:7, the mother who cannot respond to that desire reverses the process, defending against her possible guilt feelings. In 4:5, the previously spoilt children now search something to eat from

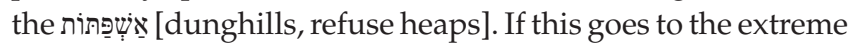
extent of eating even excrement, according to Abraham (Jones 1927:444), then the cannibalism of the mothers extends to their children who regress to combine oral with anal sadism: in an early stage of 'partial love with incorporation', a child has ambivalent feelings towards representations of the mother's body, which is both rejected and also desired, and then represented by faeces towards which an unconscious narcissistic longing remains.

The human bodies in the text are also shamed bodies. This is indicated by רָאוּ עָרְוָתָה [they have seen her nakedness] in 1:8 and

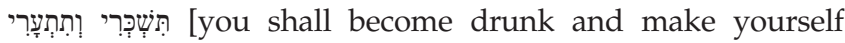
naked] in 4:21 (cf. Guest 1999), which, as public presentation of the private, both verses clearly suggesting contempt, is worse scorn than the public presentation of the body through פְּני זִתִנים [the faces of the elders] not being honoured in 5:12. Just as the hand in 5:6 is a body, part that both gives and takes, so the face is a two-way door for the body. That they both link the body to the outside world perhaps explains their prominence.

The naked female body is therefore not to be celebrated for its aesthetic nature as it is in the Song of Songs. Instead, it

34.See $2: 19$ and $4: 9$ where בעy [hunger] is explicitly mentioned; in $4: 3-5$ where it is implied; cf. also 5:4 for thirst being exploited, and 5:6, 9, 10 for hard labour just to earn food. All of this adds another sense of emptiness. implies sin, uncleanness and guilt. Two different bodies are, however, referred to in 1:8 and 4:21 but both are female: in the first, it is Jerusalem, probably standing metonymically for Judah in total, and in the second, it is בֶּר [Edom's daughter]. This shameful female nakedness stands in contrast to men who wear clothes in 4:14 even when that leaves them טָמֵא [unclean] ${ }^{35}$ as well in 4:15: the shamefulness of the bodies is not vested in the bodies as such, but in their behaviour. In the case of female bodies, it is their sexual and in the case of male bodies it is their violent behaviour that renders them unclean and sinful. Nakedness is also suggested in 3:4 where the waning flesh and skin, having served as some kind of 'clothing' (cf. Frevel 2017:204) that God דִ̣ [has worn out], is linked to starvation (vide supra) and possible illness as a consequence.

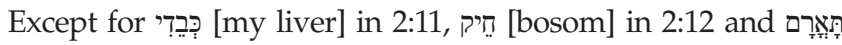
[their visage, outline] in $4: 8$, there are no exceptional body parts or special names for body parts as would have been expected in poetry as it is in the book of Job where about 68 occur of which many are uncommon (Schellenberg 2016:122-126)

Different from Psalm 22 and the Song of Songs where body references are repeatedly found in the same context as references to animals, the book of Lamentations does not do

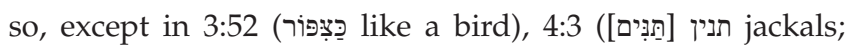

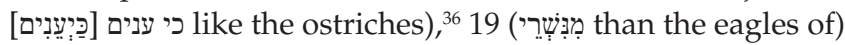

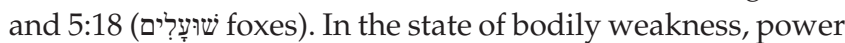
has been projected onto the horn of an animal and then internalised in 2:3, as if humans or a human group also have horns, just as it is in Zechariah 2:1, 2, 4 and Jeremiah 48:25, for instance.

One would expect the body facing death to be experiencing more intensely and therefore to be trapped in suffering silence (Scarry 1985:33). The context is indeed that of death, קינות איכה ('E Jukhôh, how!), also (funeral dirges, which it is only partially), a word that does, however, not occur in the text (Crüwell 2012:109). This is reflected in the 3:2 metre ${ }^{37}$, which is so typical of this poetic form (Shea 1979:passim). It is recited at the festival of Tisha Ab on the ninth of the month of $\mathrm{Ab}$ to commemorate amongst other catastrophes, the destruction of both temples (and therefore a collective death because of the attack on the heart of God's earthly presence) and after the death of a relative. Even their origin starts just after the fall off Jerusalem and means that they are born from death, crisis and trauma, yet grew into its present body over the next 150 years (Schwienhorst-Schönberger 2017:165).

\section{Conclusion}

Some of the bodies in the Book of Lamentations are burnt, broken, hungry, thirsty, imprisoned, exploited, exhausted

35.See הָדְנד [as unclean] in 1:17

36.See Job 39:16

37.This is critiqued by Berges (2002:79) who refers to Budde (1882:19), the originator of this idea himself who admitted that the essence of this specific metre was actually that a longer line of verse was followed by a shorter one. 
and shamed. As punished bodies, they lament their own condition, which is not only because of an unhealthy but also because of an immoral life style.

On the other hand, there are abusive bodies dominating through their hands (15 out of 20 instances), while witnessed by the victim's eyes (weak or weeping in 9 out of 10 instances), the 2 body parts most mentioned in Lamentations when נפש is ignored because of its plurality of meanings.

Being part of a religious canon, this book shows that the utter and extreme suffering of the body is not hidden behind promises of paradisiacal dreams of salvation but honestly faced in its gruesome depiction.

\section{Acknowledgements Competing interests}

The author declares that he has no financial or personal relationships which may have inappropriately influenced him in writing this article.

\section{References}

Baumann, G., 2003, 'Das göttlichen Geschlecht. JHWHs Körper und die Gender-Frage', in Hedwig-Jahnow-Forschungsprojekt (ed.), Körperkonzepte im Ersten Testament. Aspekte einer FeministischenAnthropologie, pp. 220-250, Kohlhammer, Stuttgart.

Berges, U., 2002, Klagelieder: übersetzt und ausgelegt, Herder, Freiburg.

Bester, D., 2007, Körperbilder in den Psalmen. Studien zu Psalm 22 und verwandten Texten, Mohr Siebeck, Tübingen.

Boase, E., 2014, 'The traumatized body: Communal trauma and somatization in lamentations', in E.-M. Becker (ed.), Trauma and traumatization in individual and collective dimensions: Insights from biblical studies and beyond, pp. 193-209, Vandenhoeck \& Ruprecht, Göttingen.

Breuer, J. \& Freud, S., 1955, 'Studies on Hysteria (1895 [1893-1895])', in J. Strachey \& A. Freud (eds.), Complete psychological works, Standard edition, vol. 2, 335 p., Hogarth, London.

Brown, F., Driver, S.R. \& Briggs, C.A., 1907, A Hebrew and English Lexicon of the Hebrew Bible with an appendix containing the Biblical Aramaic, Clarendon, Oxford.

Budde, K., 1882, 'Das hebräische Klagelied', Zeitschrift für die Alttestamentliche Wissenschaft 2, 1-52. https://doi.org/10.1515/zatw.1882.2.1.1

Cottrill, A.C., 2008, 'The articulate body: The language of suffering in the laments of the individual', in N.C. Lee \& C. Mandolfo (eds.), Lamentations in ancient and contemporary cultural contexts, pp. 103-112, Society of Biblical Literature, Atlanta, GA.

Crüwell, H., 2012, 'Das alphabet der Klage', in K. Christoph (ed.), "...denn das ist der ganze Mensch": Die Textrolle der jüdischen Feste: Kohelet, Esther, Hoheslied, Ruth, Klagelieder, pp. 103-126, Katholisches Bibelwerk, Stuttgart.

Dhorme, E., 1963, L'emploi métaphorique des noms de parties du corps en hébreu et en akkadien, Geuthner, Paris.

Douglas, M., 1966, Purity and danger: An analysis of the concepts of pollution and taboo, Frederick A. Praeger, New York.

Freud, S., 1998, 'X: Vorlesung: Die Symbolik in Traum', in A. Freud (ed.), Gesammelte Werk chronologisch geordnet, Band XI: Vorlesungen zur Einführung in die Psychoanalyse, pp. 150-172, S. Fischer, Frankfurt am Main.

Freud, S., 2008a, 'I: Die wissenschaftliche Literatur der Traumprobleme', A. Freud (ed.), in Gesammelte Werk chronologisch geordnet, Band II/III: Die Traumdeutung. Über den Traum, pp. 1-99, S. Fischer, Frankfurt am Main.

Freud, S., 2008b, 'VI: Die Traumarbeit', in A. Freud (ed.), Gesammelte Werk chronologisch geordnet, Band II/III: Die Traumdeutung. Über den Traum, pp. 283-512, S. Fischer, Frankfurt am Main.

Frevel, C., 2017, Die Klagelieder, Verlag Katholisches Bibelwerk, Stuttgart.

Guest, D., 1999, 'Hiding behind the naked women in lamentations: A recriminative response', Biblical interpretation 7(4), 413-448. https://doi.org/10.1163/156851599X00308
Gillmayr-Bucher, S., 2004, 'Body images in the Psalms', Journal of the Study of the Old Testament 28, 301-326. https://doi.org/10.1177/030908920402800304

Hillers, D.R., 1992, Lamentations: A new translation with introduction and commentary, Doubleday, New York.

Hunter, J., 1996, Faces of a lamenting city, Peter Lang, Frankfurt am Main.

Jones, E. (ed.), 1927, Selected papers of Karl Abraham, Hogarth, London.

Jung, C.G., 1984, Dream analysis: Notes of the seminar given in 1928-1930, Princeton University Press, Princeton.

Kaiser, O., 1992, 'Klagelieder: übersetzt und erklärt', in K. Otto (ed.), Das Hohelied. Klagelieder. Das Buch Ester, pp. 91-198, Vandenhoeck \& Ruprecht, Göttingen.

Kipfer, S. \& Schroer, S., 2015, 'Der Körper als Gefäß. Eine Studie zur visuellen Anthropologie des Alten Orients', lectio difficilior 1/2015, viewed 21 March 2018 from http://www.lectio.unibe.ch.

Koenen, K., 2015, Klagelieder (Threni) 1,1-5,22, Neukirchener, Neukirchen-Vluyn.

Kövecses, Z., 2002, Metaphor: A practical introduction: Exercises written with Szilvia Csábi, Oxford University Press, Oxford.

Lacan, J., 1949, 'Le Stade du miroir comme formateur de la fonction du Je: telle qu'elle nous est révélée dans l'expérience psychanalytique', Revue française de psychanalyse octobre - decembre, 449-455.

Lakoff, G. \& Kövecses, Z., 1983, The cognitive model of anger inherent in American English, Linguistic Agency University of Trier, Trier.

Leder, D., 1990, The absent body, Chicago University Press, Chicago.

Lee, N.C. \& Mandolfo, C., 2008, Lamentations in ancient and contemporary cultural contexts, Society of Biblical Literature, Atlanta, GA.

Markschies, C., 2016, Gottes Körper: Jüdische, christliche und pagane Gottesvorstellungen in der Antike, C. H. Beck, Munich.

Mauron, C., 1963, Des métaphores obsédantes au mythe personnel: Introduction à la psycho-critique, José Corti, Paris.

Richards, I.A., 1936, The philosophy of rhetoric, Oxford University Press, Oxford.

Saxe, G.N., Chinman, G., Berkowitz, R., Hall, K., Lieberg, G., Schwartz, J. et al., 1994 'Somatization in patients with dissociative disorders', American Journal of Psychiatry 151(9), 1329-1334. https://doi.org/10.1176/ajp.151.9.1329

Scarry, E., 1985, The body in pain, Oxford University Press, New York.

Scarry, E., 1988, Literature and the body: Essays on populations and persons, Johns Hopkins University Press, Baltimore.

Schellenberg, A., 2016, 'Mein Feisch ist gekleidet in Maden und Schorf (Hi 7,5). Zur Bedeutung des Körpers im Hiobbuch', in G. Etzelmüller \& A. Weissenrieder (eds.) Verkörperung als Paradigma theologischer Anthropologie, pp. 95-126, de Gruyter, Berlin.

Schroer, S. \& Staubli, T., 1998, Die Körpersymbolik der Bibel, Wissenschaftliche Buchgesellschaft, Darmstadt.

Shea, W.H., 1979, 'The qinah structure of the book of Lamentations', Biblica 60, 103-107.

Sommer, B., 2009, The bodies of God and the world of ancient Israel, Cambridge University Press, Cambridge.

Schart, A., 1999, 'Die "Gestalt" YHWHs: Ein Beitrag zur Körpermetaphorik alttestamentlicher Rede von Gott', Theologische Zeitschrift 55(1), 26-43.

Schwienhorst-Schönberger, L., 2017, 'Poesie und Weisheit', in W. Dietrich (ed.), Die Welt der Hebräischen Bibel: Umfeld, Inhalte, Grundthemen, pp. 151-169, Kohlhammer, Stuttgart.

Tsur, R., 2000, 'Metaphor and figure-ground relationship: Comparisons from poetry, music, and the visual arts', PsyArt: An Online Journal for the Psychological Study of the Arts, viewed 21 March 2018, from http://psyartjournal.com/article/show/ tsur-metaphor_and_figure_ground_relationship_

Van der Kolk, B.A. \& Fisler, R., 1995, 'Dissociation and the fragmentary nature of traumatic memories: Overview and exploratory study', Journal of Traumatic Stress 8(4), 505-525. https://doi.org/10.1002/jts.2490080402

Van der Zwan, P., 2017, 'The body in poverty - Ps 22', Journal for Semitics 26(1), 66-85. https://doi.org/10.25159/1013-8471/3108

Van der Zwan, P., 2018, 'The traumatised body in Daniel 2:32-35 seen from a psychoanalytic perspective', HTS Teologiese Studies/Theological Studies 74(3). https://doi.org/10.4102/hts.v74i3.5095

Wagner, A., 2006, Emotionen, Gefühle und Sprache im Alten Testament, Vier Studien, KUSATU 7, Hartmut Spenner, Waltrop.

Wagner, A., 2010, Gottes Körper: zur Alttestamentlichen Vorstellung der Menschengestaltigkeit Gottes, Verlagshaus, Gütersloh.

Wilson, K.M., 2012, 'Daughter Zion speaks in Auschwitz: A post-Holocaust reading of Lamentations', Journal for the Study of the Old Testament 37(1), 93-108. https:// doi.org/10.1177/0309089212457515

Wolff, H.W., 2002, Anthropologie des Alten Testaments, Christian Kaiser, Gütersloh.

Wolff, H.W., 2010, Anthropologie des Alten Testaments, WBG, Darmstadt.

Wutz, F.X., 1930, 'Untersuchungen zu den Klageliedern', Klerusblatt 14(15), 185-187, 202-206. 